\title{
Integrated methods for weed control in the 'Natal' orange tree
}

\section{Métodos integrados controle das plantas daninhas na laranjeira 'Natal'}

\author{
Leandro Vidotti Vila REAL ${ }^{*}$; Nelson JAYME NETO²; Cecília Giolo FAVARO3; Pedro Luís da Costa Aguiar ALVES ${ }^{4}$ \\ ${ }^{1}$ Eng. Agr., Departamento de Biologia Aplicada à Agropecuária da Faculdade de Ciências Agrárias e Veterinárias - UNESP - \\ Câmpus Jaboticabal, SP. E-mail.: levidotti@yahoo.com.br \\ 2 Eng. Agr. MSc., Departamento de Biologia Aplicada à Agropecuária da Faculdade de Ciências Agrárias e Veterinárias \\ UNESP - Câmpus Jaboticabal, SP. E-mail.: netojayme@hotmail.com \\ 3 Eng. Agr. MSc., Departamento de Biologia Aplicada à Agropecuária da Faculdade de Ciências Agrárias e Veterinárias - \\ UNESP - Câmpus Jaboticabal, SP. E-mail.: ceci_giolo@hotmail.com \\ ${ }^{4}$ Eng. Agr. Professor Titular da Faculdade de Ciências Agrárias e Veterinárias - UNESP - Câmpus Jaboticabal, SP. E-mail.: \\ pl.alves@unesp.br
}

Recebido em: 01-09-2020; Aceito em: 21-07-2021

\begin{abstract}
One of the main critical points in the production process of orange trees is the negative interference imposed by weeds. Considering the relevance of this factor, this study aims to evaluate integrated methods for weed control on the yield of orange (Citrus sinensis L.), cv. 'Natal'. A field experiment was carried out in a randomized block design with the following nine treatments: manual weeding of the area associated with maintenance with herbicide; herbicide application in the total area; herbicide application in the total area followed by sowing of jack bean (Canavalia ensiformis L.) between the rows; herbicide application in the total area followed by sowing of the legume in the total area; herbicide application between the rows only in the free space between canopies; herbicide application in the row; herbicide application in the canopy projection; herbicide application in the total area except for the canopy projection; besides a control treatment, without weeding. The herbicide used was glyphosate, always applied at a dose of $1,080 \mathrm{~g} \mathrm{ha}^{-1}$. Among the studied managements, it can be concluded that the manual weeding of the area associated with maintenance with glyphosate $\left(1,080 \mathrm{~g} \mathrm{ha}^{-1}\right)$; glyphosate application in the total area; glyphosate application in the total area followed by sowing of jack bean between the rows; glyphosate application in the total area followed by sowing of jack beans in the total area; and glyphosate application in the canopy projection resulted in the same yield as the traditional management adopted by the farmer, which consists of glyphosate application in the row. On the other hand, glyphosate application in the total area except for the canopy projection and glyphosate application between the rows only in the free space between canopies were not good weed control methods, resulting in lower yield, whose value was similar to that of the control without weeding (in the bush).
\end{abstract}

\section{Additional keywords: Canavalia ensiformis; Citrus sinensis; competition; glyphosate; herbicide.}

\begin{abstract}
Resumo
Um dos principais pontos críticos no processo de produção das laranjeiras é a interferência negativa imposta pelas plantas daninhas. Considerando a relevância deste fator, o trabalho objetivou avaliar métodos integrados de controle das plantas daninhas sobre a produtividade da laranjeira (Citrus sinensis L.) cv. Natal. Um experimento de campo foi realizado no delineamento experimental de blocos casualizados, com nove tratamentos: capina manual da área associada a manutenção com herbicida; aplicação de herbicida em área total; aplicação de herbicida em área total, seguida de semeadura de feijão-de-porco (Canavalia ensiformis L.) na entrelinha; aplicação de herbicida em área total, seguida da semeadura da leguminosa em área total; aplicação de herbicida na entrelinha apenas no vão livre entre as copas; aplicação de herbicida na linha; aplicação de herbicida na projeção da copa; aplicação de herbicida em área total, menos na projeção da copa; além de uma testemunha sem capina. O herbicida utilizado foi o glyphosate, aplicado sempre na dose de $1.080 \mathrm{~g} \mathrm{ha}^{-1}$. Dentre os manejos estudados, pode-se concluir que capina manual da área associada a manutenção com glyphosate $\left(1.080 \mathrm{~g} \mathrm{ha}^{-1}\right)$, aplicação de glyphosate em área total, aplicação do glyphosate em área total, seguida de semeadura de feijão-deporco na entrelinha, aplicação do glyphosate área total, seguida da semeadura do feijão-de-porco em área total e aplicação de glyphosate na projeção da copa resultaram em mesma produtividade que o manejo tradicional, adotado pelo produtor, que é a aplicação de glyphosate na linha. Já a aplicação de glyphosate em área total, menos na projeção da copa e a aplicação deste herbicida na entrelinha apenas no vão livre entre as copas não se mostraram bons métodos de controle das plantas daninhas, resultando em menor produtividade, cujo valor se assemelhou ao da testemunha sem capina (no mato).
\end{abstract}

Palavras-chave adicionais: Canavalia ensiformis; Citrus sinensis; competição; glyphosate; herbicida.. 


\section{Introduction}

The Brazilian citrus production represents one of the most important agribusiness production chains in the country, as besides being profitable, it generates jobs, increases capital circulation, and favors regional development (Zulian et al., 2013). However, one of the critical and relevant points in the production process is the negative interference exerted by weeds in the crop (Gonçalves et al., 2018). Weeds can compete with citrus plants, including orange trees, for water, light, and nutrients, and when one of these factors is limiting to the plants, there is less vegetative development, lower yield and production of low-quality fruit (Bortolazzo, 2002; Carvalho et al., 2015).

In the case of the orange crop, one of the most used herbicides for the chemical control of weeds is glyphosate (Foresti et al., 2015), which has systemic action and a broad spectrum of control. However, given its intensive use, it has selected resistant weeds, such as the sourgrass - Digitaria insularis (L.) Fedde (Carvalho et al., 2012, 2013), white grass - Chloris polydactyla (L.) Sw.- (Barroso et al., 2014), and the horseweed - Conyza spp. (Bressanin et al., 2014) and tolerant weeds, such as the tropical spiderwort Commelina benghalensis L., coatbuttons - Tridax procumbens L., and Cinderella weed - Synedrellopsis grisebachii Hieron. \& Kuntze (Santos et al., 2016), which normally infest orange groves (Pinotti et al., 2009).

On the other hand, there are several cover crop species with allelopathic potential that can contribute to weed control (Linares et al., 2008). Weed emergence can be suppressed by the production of secondary metabolites called allelochemicals, which are released into the environment due to plant residue decomposition or by exudation, possibly interfering with germination and acting on dormancy mechanisms and on the initial growth of plants (Gomes Jr. \& Christoffoleti, 2008; Monquero et al., 2009). In addition, cover crops can suppress weeds in agricultural systems by competing for available resources and promoting conditions that are unfavorable for their germination and establishment (Cherr et al., 2006), besides contributing to the reduction of the weed seed bank in the soil (Sodré Filho et al., 2008).

Thus, the use of legumes as green manure and in weed management is an alternative for production systems, as observed in sugarcane by Dantas et al. (2015). Among the legumes used as green manure, jack bean (Canavalia ensiformis L.) is one of the most suitable for intercropping due to its morphological and physiological characteristics (Perin et al., 2007), besides its allelopathic potential (Dinardo et al., 1998; Campana et al., 2018). For example, several studies have shown the beneficial effect of intercropping maize with jack beans, highlighting the decrease in the weed population and the increase in the amount of dry matter in the organic no-tillage system (Fontanetti, 2008).

Therefore, the integration of control methods solves the problem of interference with minimal environmental impact. When control methods are carried out in an integrated manner, it is even possible to take advantage of the beneficial effect that weeds can provide, such as increased biotic diversity and increased protection of the soil surface against the process of erosion and immobilization of large amounts of nutrients (Pitelli, 1985; Linares et al., 2008).

Considering the information now available, it is hypothesized that the chemical control of weeds with glyphosate in different areas and locations within the orange orchard, associated or not with the cultivation of a legume, could provide increased yield. Thus, this study aims to evaluate the effect of integrated methods for weed control in the yield of 'Natal' orange trees.

\section{Material and methods}

The experiment was carried out in an orange orchard, cultivar 'Natal', grafted on 'Rangpur' limw (Citrus limonia (L.) Osbeck), at Fazenda Lagoinha, municipality of Barretos, São Paulo State, from January 2000 to January 2001. The experimental area was selected according to its history of high density of infestation by several weed species, especially palisade grass (Urochloa decumbens Stapf.), low amaranth (Amaranthus deflexus L.), prickly sida (Sida glaziovii K. Schum.), and dropseed (Spermacoce latifolia Aubl.).

The experiment was carried out in a randomized block design, with nine treatments in three replicates, totaling 27 experimental plots. The experimental area was demarcated so that the plots contained twelve orange trees in a spacing of $6 \times 7 \mathrm{~m}$, totaling $504 \mathrm{~m}^{2}$ per plot. The two central plants in the plots were considered as the usable area, corresponding to $84 \mathrm{~m}^{2}$. At the time of the experiment, the plants were 11 years old.

The treatments consisted of different control locations and methods of maintaining the orange trees free from weed interference, as described in Table 1.

The legume used in Treatments 4 and 5 was the jack bean (Canavalia ensiformis L.). The legume was sown manually 35 days after herbicide application, on $03 / 18$, in a spacing of $0.30 \mathrm{~m}$ between plants and using a manual seed planter. The cleaning of the area, either through manual weeding or through herbicide application, was carried out whenever the weeds reached high infestation levels according to the farmer's criteria, thus justifying its control. 
Table 1 - Description of experimental treatments.

\begin{tabular}{c|l|}
\hline \hline TREATMENTS & \multicolumn{1}{c|}{ DESCRIPTION OF TREATMENTS } \\
\hline 01 & Control without weeding (in the bush). \\
\hline 02 & $\begin{array}{l}\text { Manual weeding followed by maintenance with herbicide. } \\
\text { Herbicide application in the total area. }\end{array}$ \\
\hline 04 & $\begin{array}{l}\text { Herbicide application in the total area followed by sowing of the legume } \\
\text { between rows. } \\
\text { Herbicide application in the total area followed by sowing of the legume } \\
\text { in the total area. }\end{array}$ \\
\hline 05 & $\begin{array}{l}\text { Herbicide application between the rows only in the free space between } \\
\text { canopies. }\end{array}$ \\
\hline 07 & \begin{tabular}{l} 
Herbicide application in the row (farmer's management). \\
\hline 08
\end{tabular} \\
\hline 09 & $\begin{array}{l}\text { Herbicide application in the canopy projection. } \\
\text { Herbicide application in the total area, except for the canopy projection. }\end{array}$ \\
\hline \hline
\end{tabular}

The herbicide used was glyphosate (Roundup Original - $360 \mathrm{~g} / \mathrm{L}$ glyphosate acid equivalent). Doses of $1,080 \mathrm{~g} \mathrm{ha}^{-1}$ were used in all applications. During the experimental period, three herbicide applications were carried out in all treatments, except for Treatments 1, 4, and 5; the first application (02/03/2000) presented air temperature at $31.0^{\circ} \mathrm{C}$ and relative humidity of $65 \%$; the second application (03/09/2000) presented air temperature at $33^{\circ} \mathrm{C}$ and relative humidity of $52 \%$; and the third (11/05/2000) presented air temperature at $21.5^{\circ} \mathrm{C}$ and relative humidity of $31 \%$. All applications were carried out in the morning using a $\mathrm{CO}_{2}$-pressurized backpack sprayer fitted with a boom with four spraying nozzles (XR 110.02) regulated for a spray volume of $200 \mathrm{~L} \mathrm{ha}^{-1}$ at a pressure of $40 \mathrm{lbf} / \mathrm{in}^{2}$.

During the experiment, the experimental plots were subjected to cultural treatments according to the farmer's procedure. One day before the implementation of the experiment, an informal survey of the weed community that infested the area was carried out by random walking, following the procedure described by Maguran (1988). During each herbicide application, the weed community was evaluated visually and visual scores of general coverage were assigned on a scale from 0 to $100 \%$, being always performed by three people, noting that in the first application, on $02 / 03$, the plots were practically $100 \%$ covered with the community described in Table 2. Besides the evaluations aforementioned, the other evaluations were carried out 30 days after the second application, on 04/08, and 90 days after the third and last application.

The production of the two usable plants of each experimental plot was evaluated in two harvests, one in December 2000 and another in January 2001, when the total mass of the bags with oranges harvested per plant was determined, as well as the number of oranges picked by bag. After obtaining the total mass, the yield $\left(\mathrm{kg} \mathrm{plant}^{-1}\right)$ was determined, which was also expressed in box weight per plant by dividing the yield by the mass of the box weight $(40.8 \mathrm{~kg})$.

The results of weed community coverage rate, number of fruits per bag, and yield of orange trees were subjected to analysis of variance by $\mathrm{F}$ test with means compared by Tukey test at $5 \%$ probability. To perform these analyses, the statistical software AgroEstat was used.

\section{Results and discussion}

Table 2 lists the weeds that occurred in the experimental area. The weed community during the experimental period basically consisted of 16 species. As for the botanical classification, there was a predominance of eudicotyledons, comprising $75.0 \%$ of the total number of species.

Pinotti et al. (2009), who carried out a floristic survey of weeds in an orange orchard, cultivar 'Pêra' grafted on 'Rangpur' lime in the municipality of Garça, São Paulo, identified 16 species belonging to eight different families; out of these species, five were also found in this experiment, namely: low amaranth (Amaranthus spp.), black-jack (Bidens pilosa), tropical spiderwort (Commelia bengalensis), palisade grass (Urochloa decumbens), and southern sandbur (Cenchrus echinatus). On the other hand, Fávaro (2016), who also carried out a floristic survey in an orchard of 'Pera' grafted on 'Rangpur' lime in Monte Azul, São Paulo State, found that the weed community consisted of 24 weed species belonging to nine plant families, out of which three were monocotyledons and six eudicotyledons, with nine of these species being also found in this study, except for the common purslane and pau-fava, demonstrating the predominance of eudicotyledons. 
Table 2 - Weed species present in the experimental area with their common and scientific name and their respective plant families.

\begin{tabular}{lcll}
\hline \hline COMMON NAME & & SCIENTIFIC NAME & FAMILY \\
\hline Sourgrass & $(2)$ & Digitaria insularis (L.) Fedde. & Poaceae \\
Signalgrass & $(2)$ & Urochloa decumbens Stapf. & Poaceae \\
Southern sandbur & $(2)$ & Cenchrus echinatus L. & Poaceae \\
Guinea grass & $(2)$ & Panicum maximum Jacq. & Poaceae \\
Joyweed & $(1)$ & Alternanthera tenella L. & Amaranthaceae \\
Low amaranth & $(1)$ & Amaranthus deflexus L. & Amaranthaceae \\
Globe amaranth & $(1)$ & Gomphrena globosa L. & Amaranthaceae \\
Black-jack & $(1)$ & Bidens pilosa L. & Asteraceae \\
Sicklepod & $(1)$ & Senna obtusifolia L. & Caesalpiniaceae \\
Tropical spiderwort & $(2)$ & Commelina benghalensis L. & Commelinaceae \\
Whitemouth dayflower & $(1)$ & Chamaesyce hirta L. & Euphorbiaceae \\
Greater celandine & $(1)$ & Chamaesyce hyssopifolia (L.) Small & Euphorbiaceae \\
Prickly sida & $(1)$ & Sida glaziovii K. Schum. & Malvaceae \\
Common purslane & $(1)$ & Portulaca oleracea L. & Portulacaceae \\
Dropseed & $(1)$ & Spermacoce latifolia Aubl. & Rubiaceae \\
Mexican clover & $(1)$ & Spermacoce verticillata (L.) G.Mey & Rubiaceae \\
\hline \hline
\end{tabular}

(1) - eudicotyledon.

(2) - monocotyledon.

During the experimental period, it was found that the control plots maintained weed coverage above $95 \%$ (Table 3). In the evaluation carried out at 30 DA1stA in the area, dropseed $(45 \%)$, signalgrass $(15 \%)$, sida $(9 \%)$, swallowgrass $(7 \%)$, greater celandine $(5 \%)$, paufava $(3 \%)$, southern sandbur $(2 \%)$, and tropical spiderwort $(2 \%)$ were highlighted regarding weed coverage rate (data not shown). On that occasion, the herbicide applications in the row or only in the canopy projection resulted in an average coverage rate of $68.3 \%$, which did not differ from the control, while the other managements, although not differing between them, provided coverage ranging from $6 \%$ to $21.7 \%$ and presented significantly lower rates than the control and herbicide applications in the row or only in the canopy projection.

Table 3 - Weed coverage rate in the plots in response to treatments used during the experimental period.

\begin{tabular}{|c|c|c|c|c|}
\hline \multirow[b]{2}{*}{ TREATMENTS } & \multicolumn{4}{|c|}{ Coverage $(\%)-$ day/month } \\
\hline & $\begin{array}{c}\text { Second } \\
\text { application - } \\
9 / 3 \\
\text { (30DA1stA) }\end{array}$ & $\begin{array}{c}8 / 4 \\
\left(30 \mathrm{DA} 2^{\mathrm{a}} \mathrm{A}\right)\end{array}$ & $\begin{array}{c}\text { Third } \\
\text { application - } \\
11 / 5 \\
\text { (60DA2ndA) }\end{array}$ & $\begin{array}{c}18 / 8 \\
(90 \mathrm{DA} 3 \mathrm{rdA})\end{array}$ \\
\hline 1. Control without weeding. & $98.30 \mathrm{a}$ & $98.30 \mathrm{a}$ & $95.00 \mathrm{a}$ & $95.0 \mathrm{a}$ \\
\hline $\begin{array}{l}\text { 2. Manual weeding followed by maintenance with } \\
\text { herbicide. }\end{array}$ & $6.00 \mathrm{c}$ & $12.20 \mathrm{c}$ & $8.90 \mathrm{~b}$ & $8.30 \mathrm{c}$ \\
\hline 3. Herbicide application in the total area. & $6.70 \mathrm{c}$ & $42.20 \mathrm{bc}$ & $20.60 \mathrm{~b}$ & $6.80 \mathrm{c}$ \\
\hline $\begin{array}{l}\text { 4. Herbicide application in the total area followed } \\
\text { by sowing of the legume between rows. }\end{array}$ & $15.00 \mathrm{c}$ & $48.90 \mathrm{bc}$ & $12.00 \mathrm{~b}$ & $12.80 \mathrm{bc}$ \\
\hline $\begin{array}{l}\text { 5. Herbicide application in the total area followed } \\
\text { by sowing of the legume in the total area. }\end{array}$ & $16.70 \mathrm{bc}$ & $28.90 \mathrm{c}$ & $8.30 \mathrm{~b}$ & $9.40 \mathrm{c}$ \\
\hline $\begin{array}{l}\text { 6. Herbicide application between the rows only in } \\
\text { the free space between canopies. }\end{array}$ & $16.70 \mathrm{bc}$ & $46.70 \mathrm{bc}$ & $3.90 \mathrm{~b}$ & $0.00 \mathrm{c}$ \\
\hline $\begin{array}{l}\text { 7. Herbicide application in the row (farmer's } \\
\text { management). }\end{array}$ & $70.00 \mathrm{a}$ & $77.70 \mathrm{ab}$ & $64.50 \mathrm{a}$ & $43.90 \mathrm{~b}$ \\
\hline 8. Herbicide application in the canopy projection. & $66.70 \mathrm{a}$ & $44.10 \mathrm{bc}$ & $20.00 \mathrm{~b}$ & $20.00 \mathrm{bc}$ \\
\hline $\begin{array}{l}\text { 9. Herbicide application in the total area, except } \\
\text { for the canopy projection. }\end{array}$ & $21.70 \mathrm{bc}$ & $36.70 \mathrm{bc}$ & $8.60 \mathrm{~b}$ & $8.50 \mathrm{c}$ \\
\hline $\begin{array}{l}\mathrm{F} \text { treatment } \\
\text { DMS } \\
\text { CV (\%) }\end{array}$ & $\begin{array}{l}13.84^{* *} \\
44.60 \\
34.38\end{array}$ & $\begin{array}{l}9.11^{* *} \\
44.60 \\
33.24\end{array}$ & $\begin{array}{l}19.13^{* \star} \\
37.50 \\
52.50\end{array}$ & $\begin{array}{l}24.65^{\star *} \\
31.20 \\
52.37\end{array}$ \\
\hline
\end{tabular}

Note: Dates of glyphosate application in the area: 02/03/, 03/09, and 05/11; DA1stA - Days after the first application, other DA2ndA - Days after the second application, DA3rdA - Days after the third application. 
After approximately 30 DA2ndA, all plots presented an increase in the weed coverage when compared to the previous evaluation, except for the control, which maintained the coverage rate. On that occasion, the weeds that visually stood out regarding coverage rate in the area were dropseed $(25 \%)$, signalgrass $(25 \%)$, greater celandine $(10 \%)$, sida $(9 \%)$, swallowgrass $(5 \%)$, sourgrass $(3 \%)$ and tropical spiderwort (3\%) (data not shown). Although weed coverage increased, all managements maintained lower values than the control, except for herbicide application in the row (farmer's management), which did not differ significantly. Manual weeding followed by herbicide application and herbicide application in the total area followed by sowing the legume in total area were the most effective treatments, reducing the weed coverage by $79 \%$ when compared to the control. The other managements, although not differing from the two treatments aforementioned, reduced coverage by $55 \%$.

On the occasion of the third glyphosate application, approximately 60 days after the second, it was found that, in general, the coverage rate reduced even in the control without weeding, a result that may be caused by the reduction in rainfall and temperature, which is common at this time of the year. The weeds that visually stood out regarding coverage rate in the area were greater celandine $(20 \%)$, signalgrass $(20 \%)$, dropseed $(10 \%$ of the cover), sourgrass $(5 \%)$, tropical spiderwort $(5 \%)$, prickly sida $(5 \%)$, and swallowgrass (2\%) (data not shown).

Similar to what happened in the previous evaluation, all managements provided a reduction in coverage, except for the herbicide application in the row, which did not differ significantly, while the other managements did not differ from each other and provided an average reduction of $88 \%$ in the weed coverage rate.

In the evaluation carried out $90 \mathrm{DA} 3 \mathrm{rdA}$, a period when the lack of rain predominates, it was found that all treatments presented a coverage rate similar to the previous evaluation (60DA2ndA), being effective in the control of weeds in relation to the farmer's management (herbicide application in the row). Manual weeding followed by maintenance with herbicide, herbicide application in the total area, herbicide application in total area followed by sowing of the legume in the total area, herbicide application between rows only in the free space between canopies, and herbicide application in the total area except for the canopy projection were the most effective managements, providing an average reduction of $93 \%$ in weed coverage, while the farmer's management provided a $54 \%$ reduction.

When analyzing the effect of the treatments on the productive characteristics of the 'Natal' orange tree (Table 4), there was no statistical difference in the number of fruits per bag, that is, none of the treatments changed the size of the harvested fruits. However, when yield was analyzed regarding the mass of fresh fruit produced, it was found that herbicide application in the total area followed by sowing of the legume between the rows resulted in higher yield per plant when compared to the control without weeding, with an increase of $29.8 \%$, followed by herbicide application in the total area $(23.7 \%)$, manual weeding followed by maintenance with herbicide (23.4\%), herbicide application in the total area followed by sowing of the legume in the total area (21.4\%), and herbicide application in the canopy projection or row $(18.5 \%$, on average).

Table 4 - Results of the analysis of variance for the effect of treatments on yield characteristics of the 'Natal' orange tree.

\begin{tabular}{|c|c|c|}
\hline TREATMENTS & № fruits bag $^{-1}$ & Yield $\left(\right.$ kg plant $\left.^{-1}\right)$ \\
\hline 1. Control without weeding. & 159.30 & $69.51 \mathrm{~d}$ \\
\hline 2. Manual weeding followed by maintenance with herbicide. & 192.10 & $85.78 \mathrm{ab}$ \\
\hline 3. Herbicide application in the total area. & 183.80 & $86.04 a b$ \\
\hline $\begin{array}{l}\text { 4. Herbicide application in the total area followed by sowing of } \\
\text { the legume between rows. }\end{array}$ & 144.70 & $90.26 \mathrm{a}$ \\
\hline $\begin{array}{l}\text { 5. Herbicide application in the total area followed by sowing of } \\
\text { the legume in the total area. }\end{array}$ & 185.10 & $84.42 \mathrm{abc}$ \\
\hline $\begin{array}{l}\text { 6. Herbicide application between the rows only in the free space } \\
\text { between canopies. }\end{array}$ & 197.40 & $65.01 \mathrm{~d}$ \\
\hline 7. Herbicide application in the row (farmer's management). & 174.00 & $82.31 \mathrm{abc}$ \\
\hline 8. Herbicide application in the canopy projection. & 167.50 & $82.29 a b c$ \\
\hline $\begin{array}{l}\text { 9. Herbicide application in the total area, except for the canopy } \\
\text { projection. }\end{array}$ & 198.90 & $62.11 \mathrm{~d}$ \\
\hline F Treat. & $1.10^{\text {ns }}$ & $23.32^{* \star}$ \\
\hline DMS & 87.90 & 12.22 \\
\hline CV (\%) & 16.98 & 5.58 \\
\hline
\end{tabular}

1. Means followed by the same letter in the column did not differ from each other at the $1 \%$ probability level by Tukey's test. CV = Coefficient of Variation; DMS = minimum significant difference. 
The treatments aforementioned did not differ from each other. On the other hand, herbicide application between rows only in the free space between canopies and herbicide application in the total area except for the canopy projection resulted in yields equal to the control without weeding, thus being significantly inferior to the treatments listed above.

By analyzing the correlation of the results of the number of fruits harvested per bag and the total production of the plant, it was found that the highest productions obtained were mainly provided by the increase in the number of fruits produced and not by an increase in their dimensions.

Comparing the treatment that provided the highest yield (herbicide application in the total area followed by sowing of the legume between rows) with the control without weeding, it is possible to observe that the weed community with a predominance of eudicotyledons reduced the production potential of the orange grove under study by $23 \%$, and that the farmer's procedure (herbicide application in the planting row), although reducing the weed coverage by $34 \%$ on average during the experimental period, minimized weed interference on the crop yield (Table 3). It was also found that weed interference was more accentuated when weeds were found under the plant canopies, since the treatments in which there was herbicide application between rows only in the free space between canopies and herbicide application in the total area except for the canopy projection (treatments that let weeds grow under the canopy) resulted in lower yield, equaling the control without weeding. These three treatments mentioned above differed statistically from the farmer's management (Figure 1).

The presence of jack bean plants under the canopy, as in the case of sowing in the total area, provided a lower yield than that obtained with sowing of the legume only between rows. These results demonstrate that the proximity of weeds to the crop can interfere with the development and production of orange trees, since it exceeds the area bearable by the orange plants and the competition for nutrients exerted by weeds is one of the main factors that limit the growth and production of cultivated plants (Pitelli, 1985).

Plants such as the hairy wood rose (Merremia aegyptia (L.) Urb.) (Martins et al., 2010), sicklepod (Senna obtusifolia (L.) HS Irwin \& Barneby) (Bianco et al., 2008a), Sida rhombifolia L. (Bianco et al., 2008b), and Solanum americanum Mill (Bianco et al., 2010), among others, have a high capacity to extract nutrients from the soil and can be highly competitive with agricultural crops and, as a consequence, reduce the crop yield. Carvalho et al. (2012) mentioned that orange plants need good aeration and empty spaces in the soil for the development of the root system, which will ensure good plant development and high yield. Thus, it is possible to optimize its genetic potential, also avoiding the degradation of the soil physical properties.

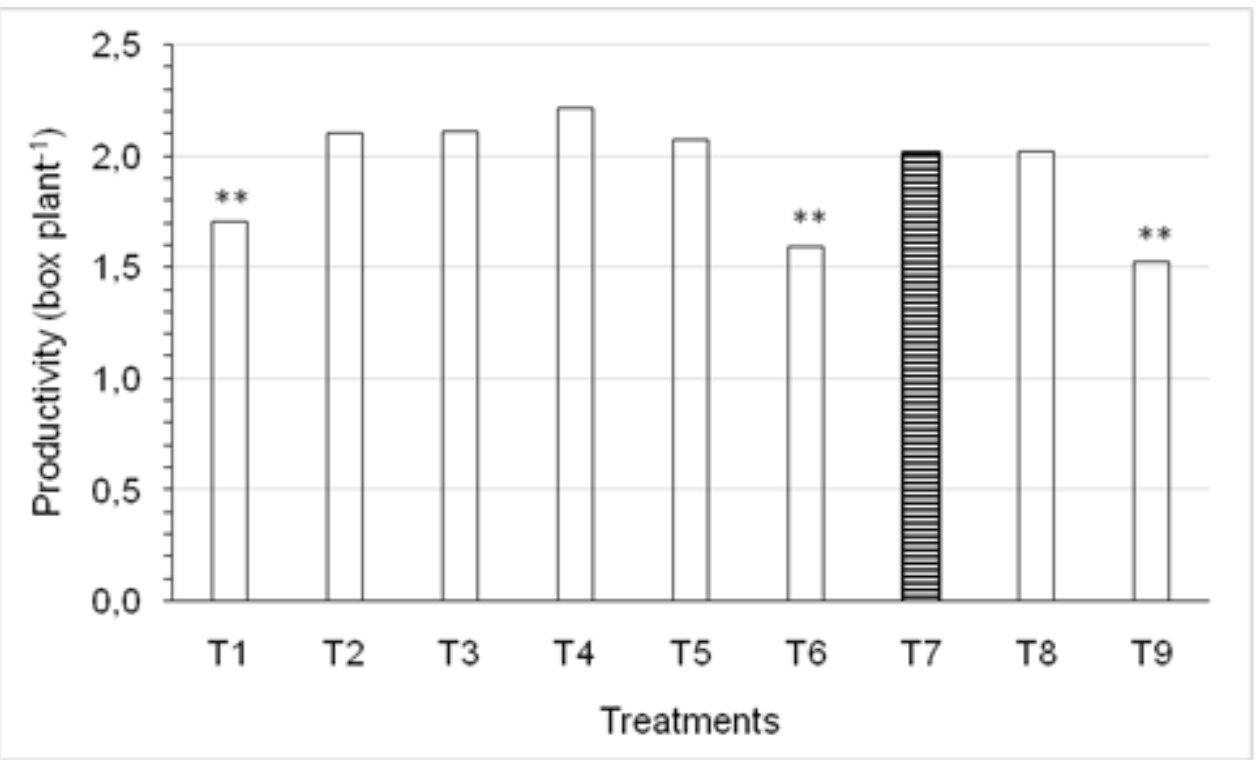

Figure 1 - Productivity of weight boxes per orange tree $(40.8 \mathrm{~kg} / \mathrm{box})$ as a function of integrated methods for weed control. $\mathrm{T} 7=$ conventional treatment by the farmer. ${ }^{* *}$ Differ significantly from $\mathrm{T} 7$.

It is noteworthy that when choosing one of the treatments, a possible environmental impact and the resulting benefits should also be considered, besides their cost. In the case of treatments with manual weeding followed by maintenance with herbicide and herbicide application in the total area, besides the environmental impact caused by herbicide applications, the soil remained practically clean and exposed to all weather conditions, that is, subject to wind and water erosion and to large thermal amplitudes. Furthermore, the absence of plants can lead to soil depletion by reducing nutrient recycling. In the case of treatments with herbicide application in the total area followed by sowing of the legume between the rows and herbicide application in total area followed by sowing of the legume in the total area, there may be the environmental 
impact of the initial application of glyphosate, but the subsequent sowing of the legume in the total area or between the rows minimizes or eliminates the previously mentioned problems that may be caused in the soil, besides enriching it with nitrogen and other nutrients and providing the crop control of the weed community (Damasceno et al., 2019). For example, Caetano et al. (2001) verified that the presence of pigeon pea (Cajanus cajan (L.) Huth) and lablab-bean (Dolichus lablab L.) between the rows of a 'Pera' orange orchard reduced weed germination.

Studies have proved that the use of mulch in fruit farming protects the soil from the impact of rain, increases water infiltration, incorporates organic matter, and improves the soil structure (Sanches, 1998). Thus, the growth conditions of the plant root system are improved and yield is consequently increased, corroborating the results obtained in the present study. Herbicide application in the row or only in the canopy projections, although may causing an environmental impact, maintains the soil partially covered with the weed community, making use of its benefits.

In the present study, the jack bean was used as intercrop as, besides providing benefits as a green manure, it is a species with recognized allelopathic effects, reducing the germination of sida (Sida cordifolia L.), Black-jack (Bidens pilosa L.), and Itchgrass (Rottboellia cochinchinensis (Lour.) Clayton) (Dinardo et al., 1998). Carvalho et al. (1997) obtained an increase in the production of 'Pera' orange using the jack bean as a vegetable cover between the rows of the crop planted in two regions of Northeastern Brazil. A similar result was obtained in the present study, in which the sowing of the legume between the rows was the treatment that provided the greatest yield gain. Apparently, the sowing of the legume in the total area including the planting row reduced the earning potential maybe due to competition exerted by the legume, as aforementioned. In another study, Carvalho et al. (2002) compared the management system used by the farmer (three manual weedings in the planting rows and three harrowings between the rows) with the management system that used jack bean as a plant cover between the rows of the 'Pêra' orange orchard and chemical weed control with glyphosate in the rows and concluded that the proposed management presented better results (above 57\%) in relation to farmer's management for fruit mass, number of fruits per plant, and yield.

This beneficial effect of the legume may be provided by its suppressive effect on the growth of weeds, consequently reducing their interference, in association with the direct effects of the legume on orange trees, as mentioned above. For example, Carvalho et al. (1999) concluded that the management of vegetation cover in orange orchards allowed for an increase and better distribution of the root system of the orange trees in the soil profile, allowing the exploitation of a greater volume of soil and ensuring more availability of water and nutrients for the 'Pêra' orange.

Therefore, in summary, it was found that the presence of weeds both in the planting rows and in the canopy projection of the 'Natal' orange tree reduced crop yield by $23 \%$, similarly to the orchard maintained without weed control, and the yield reduction was expressed in the number of fruits and not in their size. Herbicide application in the row, although reducing the weed coverage on average by $54 \%$ with a predominance of eudicotyledon, provided production similarly to the other methods, which provided an average reduction of $93 \%$ in weed coverage. Thus, the farmer should carry out a cost-benefit ratio analysis to choose, among the methods that are similar to the traditionally used, the one that will provide good yield associated with the lowest environmental impact.

\section{Conclusions}

Among the studied managements, it can be concluded that the manual weeding of the area associated with maintenance with glyphosate $(1,080 \mathrm{~g}$ $\left.\mathrm{ha}^{-1}\right)$, glyphosate application in the total area, glyphosate application in the total area followed by sowing of jack bean between the rows, glyphosate application in the total area followed by sowing of jack bean in the total area, and glyphosate application in the canopy projection resulted in the same yield as the traditional management adopted by the farmer, which is glyphosate application in the row. On the other hand, glyphosate application in the total area except for the canopy projection and herbicide application between the rows only in the free space between canopies were not good methods for weed control, resulting in lower yield, whose value was similar to that of the control without weeding (in the bush).

\section{References}

Barroso AAM, Albrecht AJP, Reis FC, Placido HF, Toledo REB, Albrecht LP, Victória Filho R (2014) Different glyphosate susceptibility in Chloris polydactyla accessions. Weed Technology 28(4): 587-591.

Bianco S, Pitelli RA, Carvalho L B (2008a) Crescimento e nutrição mineral de fedegoso. Ciência e Cultura 3(1): 35-41.

Bianco S, Carvalho LB, Bianco MS (2008b) Estudo comparativo do acúmulo de massa seca e macronutrientes por plantas de Glycine max e Sida rhombifolia. Cultura Agronômica 17(1): 75-79.

Bianco S, Carvalho LB, Bianco MS (2010) Growth and mineral nutrition of Solanum americanum. Planta Daninha 28(2): 293-299.

Bortolazzo ED (2002) Efeitos da área de controle das plantas daninhas (coroamento ou faixa) no desenvolvimento inicial de tangerina "Poncãn" (Citrus reticulata Blanco). USP (Dissertação de mestrado em Fitotecnia). 
Bressanin FN, Jayme Neto N, Martins JF, Martins JVF, Alves PLCA (2014) Controle de biótipos resistentes de Conyza bonariensis com glyphosate + clorimuronetílico em função do estádio de desenvolvimento. Revista Brasileira de Herbicidas 13(1): 68-72.

Caetano RSX, Christoffoleti PJ, Victoria Filho R (2001) "Banco" de sementes de plantas daninhas em pomar de laranjeira 'Pera'. Scientia Agricola 58(3): 509-517.

Campana J, Paulino C, Euzébio A, Endres L, Souza R, Granja B $(20,18)$ Allelopathic potential and identification of secondary metabolites in extracts of Canavalia ensiformis L. Revista Ceres 65: 243-252.

Carvalho JEB, Souza LS, Castro Jorge LA, Ramos WF, Costa Neto AO, Araújo AMA, Lopes LC, Jesus MS (1997) Manejo de coberturas do solo e sua interferência no desenvolvimento do sistema radicular da laranja 'Pera'. In: CONGRESSO BRASILEIRO DA CIÊNCIA DAS PLANTAS DANINHAS, 21. p.399.

Carvalho JEB, Souza LS, Castro Jorge LA, Ramos WF, Costa Neto AO, Araújo AMA, Lopes LC, Jesus MS (1999) Manejo de coberturas do solo e sua interferência no desenvolvimento do sistema radicular da laranja'Pêra'. Revista Brasileira de Fruticultura 21(2): 140-145.

Carvalho JEB, Souza LS, Caldas RC, Antas PEUT, Araújo AMA, Lopes LC, Santos RC, Lopes NCM, Souza ALV (2002) Leguminosa no controle integrado de plantas daninhas para aumentar a produtividade da laranja 'Pêra'. Revista Brasileira de Fruticultura 24(1): 82-85.

Carvalho JEB, Gonçalves GS, Silva JF da, Azevedo CLL (2015) Período crítico de interferência de plantas infestantes na cultura da laranja no Estado do Amazonas. (Comunicado técnico, 159).

Carvalho LB, Alves PLCA, González-Torralva F, Cruz Hipolito HE, Rojano-Delgado AM, De Prado R, GilHumanes J, Barro F, Luque De Castro M D (2012) Pool of resistance mechanisms to glyphosate in Digitaria insularis. Journal of Agricultural and Food Chemistry 60(2): 615-622.

Carvalho LB, Rojano-Delgado AM, Alves PLCA, De Prado R (2013) Differential content of glyphosate and its metabolites in Digitaria insularis biotypes. Communications in Plant Sciences 3(3-4): 17-20.

Cherr CM, Scholberg JMS, Mcsorley R (2006) Green manure approaches to crop production: a synthesis. Agronomy Journal 98: 302-319.

Damasceno LA, Carvalho JEB, Xavier FA, Santos AF, Gonçalves GS, Lima AFL, Brito WBM, Azevedo CLL,
Silva JF (2019) Weed suppression by cover plants in the Amazonian. Journal of Agricultural Science 11: 14.

Dantas RA, Carmona R, Carvalho AM, Rein TA, Malaquias JV, Santos Júnior JDG (2015) Produção de matéria seca e controle de plantas daninhas por leguminosas consorciadas com cana-de-açúcar em cultivo orgânico. Pesquisa Agropecuária Brasileira 50(8): 681-689.

Dinardo W, Pellegrini MT, Alves PLCA (1998) Inhibitory effects of jackbean (Canavalia ensiformis L.) leaf residues on germination and vigour of crops and weeds. Allelopathy Journal 5(1):35-42.

Fávaro C G (2016) Influência da área de controle de plantas daninhas na laranjeira 'Pera Rio'. Unesp (Dissertação de mestrado em Agronomia).

Fontanetti A (2008) Adubação e dinâmica de plantas daninhas em sistema de plantio direto orgânico de milho. UFV (Tese de doutorado em Fitotecnia).

Foresti ER, Nepomuceno MP, Alves PLCA (2015) Simulação da deriva de clomazone e glyphosate em mudas de laranjeira 'Hamlin'. Revista Brasileira de Fruticultura 37(2): 367-376.

Gomes Jr. FG, Christoffoleti PJ (2008) Biologia e manejo de plantas daninhas em áreas de plantio direto. Planta Daninha 26(4): 789-798.

Gonçalves GS, Carvalho JEB, Garcia MVB, Gama LA, Azevedo CLLL, Silva JF (2018) Periods of weed interference on orange tree crops. Planta Daninha $36 \mathrm{p}$. :e018179810-:e018179810, 2018.

Linares J, Scholberg J, Boote K, Chase C A, Ferguson $\mathrm{J} J$, McSorley R (2008) Use of the cover crop weed index to evaluate weed suppression by cover crops in organic citrus orchards. Hortscience 43(1): 27-34.

Maguran AE (1988) Ecological diversity and its measurement. London/Croom Helm. 179 p.

Martins TA, Carvalho LB, Bianco MS, Bianco S (2010) Acúmulo de massa seca e macronutrientes por plantas de Merremia aegyptia. Planta Daninha 28: 1023-1029. Monquero PA, Amaral LR, Inácio EM, Brunhara JP, Binha DP, Silva PV, Silva AC (2009) Efeito de adubos verdes na supressão de espécies de plantas daninhas. Planta Daninha 27(1): 85-95.

Perin A, Bernardo JT, Santos RHS, Freitas, GB (2007) Desempenho agronômico de milho consorciado com feijão-de-porco em duas épocas de cultivo no sistema orgânico de produção. Revista Ciência Agrotecnologia 31(3): 903-908. 
Pinotti EB, Sales TC, Minatel LFC, Barbosa RZ (2009) Levantamento florístico de plantas daninhas na cultura da laranja (Citrus sinensis). Revista Científica Eletrônica de Agronomia 12(15): 1-11.

Pitelli R A (1985) Interferência de plantas daninhas em culturas agrícolas. Informe Agropecuário 11(129): 1627.

Sanches AC (1998) Conservação do solo em pomares cítricos. In: Seminário internacional de citros-tratos culturais 5. Anais. p.167-187.
Santos J I, Amaral CL, Alves PLCA, Gasparino EC (2016) Can light intensity influence the tolerance of Synedrellopsis grisebachii to glyphosate? Weed Biology and Management 16(1): 1-15.

Sodré Filho J, Carmona R, Cardoso NA, Carvalho AM (2008) Culturas de sucessão ao milho na dinâmica populacional de plantas daninhas. Scientia Agraria 9(1): 7-14.

Zulian A, Dörr AC, Almeida SC (2013). Citricultura e Agronegócio Cooperativo no Brasil. Revista Eletrônica em Gestão, Educação e Tecnologia Ambiental 11(11): 2290-2306. 